\title{
The $\mathrm{VO}_{2 \max }$ plateau is not associated \\ with the anaerobic capacity in physically active subjects
}

CDD. 20.ed. 796.031

796.07

http://dx.doi.org/10.1590/1807-55092016000400865

\author{
Renata Gonçalves SILVA* \\ Marcos David SILVA-CAVALCANTE*/** \\ Rafael de Almeida AZEVEDO* \\ Adriano Eduardo LIMA-SILVA** \\ Rômulo BERTUZZI*
}

*Escola de Educação Física e Esporte

Universidade de São

Paulo, São Paulo, SP, Brasil.

${ }^{* *}$ Centro Acadêmico de Vitória, Universidade Federal de Pernambuco, Vitória de Santo Antão, PE, Brasil.

\begin{abstract}
The present study aimed to verify if the incidence of plateau is associated with anaerobic capacity. Therefore, nine physically active male (age: $23 \pm 4$ yr; body mass: $72.4 \pm 8.2 \mathrm{~kg}$; height: $176.4 \pm 6.8 \mathrm{~cm}$; VO max: $41.3 \pm 5.7 \mathrm{ml} \mathrm{kg}^{-1} \cdot \mathrm{min}^{-1}$ ) participated in the present study. The subjects in a cycle ergometer the following tests: a) maximum incremental test to determination of $\mathrm{VO}_{2} \mathrm{max}_{;}$b) six submaximal tests for determination of supra maximum demand of $\mathrm{O}_{2} ; \mathrm{c}$ ) supra maximum test for maximum accumulated oxygen deficit (MAOD) determination. The plateau was identified when the difference in the $\mathrm{VO}_{2}$ in the last two stages of incremental test was $\leq 2.1 \mathrm{ml} \cdot \mathrm{kg}^{-1} \cdot \mathrm{min}^{-1}$. It was observed an inverse correlation, although no significant, between MAOD and $\mathrm{VO}_{2}$ plateau $(r=-0,61 ; p>0,05)$. Thus, it appears that anaerobic capacity is not a decisive factor for determining the incidence of $\mathrm{VO}_{2}$ plateau in physically active individuals.
\end{abstract}

KEY WoRDS: MAOD; Oxygen deficit; Stabilization of oxygen uptake; Incremental test; Supra maximum test.

\section{Introduction}

Traditionally, maximum oxygen consumption $\left(\mathrm{VO}_{2} \max \right)$ has been used to represent the maximum aerobic capacity ${ }^{1-2}$. Presently, $\mathrm{VO}_{2} \max$ is used as an indicator of cardiorespiratory fitness ${ }^{3-8}$, running performance predictor ${ }^{6-8}$, to evaluate training related adaptations in healthy individuals ${ }^{9}$ and in patients with coronary arterial disease ${ }^{10}$, detraining ${ }^{11-12}$, mortality predictor ${ }^{13}$ and to evaluate sleeping disorder ${ }^{14}$. Thereby, $\mathrm{VO}_{2}$ max identification is important to evaluate the fitness levels in athletes as well as in high-risk groups. $\mathrm{VO}_{2} \max$ is measured via incremental tests (TI), usually performed to voluntary exhaustion. Although several variables have been considered in order to establish maximum effort ${ }^{2}$, the main characterization of $\mathrm{VO}_{2}$ max is through stabilization in oxygen consumption $\left(\mathrm{VO}_{2}\right)$ during the final stages of TI. This $\mathrm{VO}_{2}$ characterization during the final stages of TI has been termed $\mathrm{VO}_{2}$ plateau ${ }^{2}$. Theoretically, plateau refers to a stabilization or small increases $(\leq 2.1$ $\left.\mathrm{ml} \cdot \mathrm{kg}^{-1} \cdot \mathrm{min}^{-1}\right)$ of $\mathrm{VO}_{2}$, even if loads are incremented in the final stages of $\mathrm{TI}^{2}$. However, some tests are interrupted before reaching $\mathrm{VO}_{2}$ max. In this case, the value obtained is termed as peak oxygen consumption $\left(\mathrm{VO}_{2} \text { peak }\right)^{15}$. It has been suggested that plateau incidence may be related to athlete's training state, in which athletes with higher physical condition could tolerate higher levels of pain and fatigue and higher motivation to support higher loads in the final test ${ }^{16-17}$, and that the higher intensities could be related to increases in energy supply by the anaerobic metabolism ${ }^{1}$.

Provided the relevance to establish $\mathrm{VO}_{2} \max$ parameters, previous studies used one additional test to confirm if $\mathrm{VO}_{2}$ value, obtained in a traditional TI protocol, could be considered as maximum ${ }^{18-19}$. The confirmation test is performed until fatigue with constant loads and intensities near to the $\mathrm{VO}_{2}$ max. For instance, Snell et al. ${ }^{19}$ performed the confirmation test with two intensities (95\% and $105 \%$ of the maximum power in $\mathrm{TI}$ ) and, in both conditions, it were not observed significant differences between $\mathrm{VO}_{2}$ in the verification test and the $\mathrm{VO}_{2}$ max achieved in TI, even in the absence 
of plateau. This result suggest that the maximum aerobic power can be achieved during TI, even if there is no plateau in $\mathrm{VO}_{2}$.

Previous studies with trained individuals have suggested that $\mathrm{VO}_{2}$ plateau may be related to the anaerobic metabolism ${ }^{1}$. During highintensities exercises, the ATP resynthesizes occurs predominantly via anaerobic metabolism, which seems to justify, in the final stages of the incremental test, an increase in exercise intensity even with no modifications $\mathrm{VO}_{2}$ (stabilization). In a recent study, Gordon et al. ${ }^{1}$ showed a negative correlation between $\Delta \mathrm{VO}_{2}$ and maximum accumulated oxygen deficit (MAOD) in highly trained cyclists. These results indicate that individuals with higher

\section{Method}

\section{Subjects}

Nine male subjects participated in the present study $23 \pm 4$ years, $72.4 \pm 8.2 \mathrm{~kg}$ e $176.4 \pm 6.8$ $\mathrm{cm})$. They were physically active, healthy and had previous experience with exhaustion exercise. All participated in recreational sports and activities (running, soccer and tennis), however, none were engaged in competitive activities. All subjects were informed about the aims, procedures and possible risks associated with the present study and gave their informed consent prior to enrolment in the study. All subjects were free from pharmacological treatments, neuromuscular or cardiovascular disease and were non-smokers. The present study was approved by the commit of ethical research of the School of Physical Education and Sport of the University of Sao Paulo.

\section{Experimental design}

All subjects were submitted to four experimental sessions, with at least $72 \mathrm{~h}$ of interval between sessions. In the first session, subjects performed an incremental test to voluntary exhaustion in a cycle ergometer to measure $\mathrm{VO}_{2} \max$ and its respective $\mathrm{VO}_{2} \max$ power $\left(\mathrm{WVO}_{2} \max \right)$. In the following sessions (i.e., second and third) subjects were submitted to six tests with constant loads (3 tests per session) with intensities below $\mathrm{VO}_{2}$ max. Sessions as well as sub- $\mathrm{VO}_{2}$ max tests order was randomized between subjects. Tests were performed in a controlled environment with constant room anaerobic capacity have higher incidence of plateau. Given that MAOD is elevated in both aerobic and anaerobic trained individuals as compared with physical active ones ${ }^{20}$, it seems plausible to suggest a lower incidence of $\mathrm{VO}_{2}$ plateau in physical active and non-athletes individuals. However, to the present moment no study analyzed the relationship between anaerobic capacity and the $\mathrm{VO}_{2}$ plateau in individuals with low levels of physical condition.

Thus, the present study aimed to verify the relationship between anaerobic capacity measured via MAOD and the incidence of $\mathrm{VO}_{2}$ plateau in physical activity individuals. The hypothesis was that there would be positive correlations between $\mathrm{MAOD}$ and $\mathrm{VO}_{2}$ plateau.

temperature $\left(20-24^{\circ} \mathrm{C}\right)$ and with two hours of interval from the last meal. Subjects were instructed not to performed strenuous physical exercises and not to consume alcohol 48 hours before data collection. In order to avoid any possible effect of ergogenic ${ }^{21}$ and circadian cycle ${ }^{22}$, all tests were performed in the same period of the day and subjects were instructed to not consume caffeine 48 hours before tests.

\section{Anthropometric measures}

Body mass and height were measured via an electronic scale (Filizola, model ID 1500, São Paulo, Brazil) and a wood stadiometer, respectively.

\section{Incremental test}

Incremental test was performed in an electromagnetic cycle ergometer for lower limbs (Godart-Holland, Lannoy). Immediately before test, subjects remained seated on the cycle ergometer for five minutes to determine baseline $\mathrm{VO}_{2}\left(\mathrm{VO}_{2} \mathrm{LB}\right)$. The $\mathrm{VO}_{2} \mathrm{LB}$ refers to rest $\mathrm{VO}_{2}$, which was determined from the arithmetic mean of $\mathrm{VO}_{2}$ during the final 30 seconds of the rest. Three minutes after warm-up, with the inertial resistance from the equipment, subjects cycled with a cadence of $60 \mathrm{rpm}$ and increments of intensity of $30 \mathrm{~W} \cdot \mathrm{min}^{-1}$. Test was interrupted when cadence was lower than $50 \mathrm{rpm}$. Throughout test, exchange gas and heart rate (HR) were measured breath-by-breath and beat-by-beat, respectively. $\mathrm{VO}_{2}$ was measured continuously via a portable gas analyzer $(\mathrm{K} 4 \mathrm{~b} 2$ 
Cosmed, Rome, Italy), whereas the HR was assessed by heart rate monitor (Polar, Kempele, Finland). Maximum heart rate (HRmax) was established as the higher values obtained in the final test. $\mathrm{VO}_{2} \max$ was determined according to at least three of the five criterion: increases in $\mathrm{VO}_{2}$ lower than $2.1 \mathrm{ml} \cdot \mathrm{kg}^{-1} \cdot \mathrm{min}^{-1}$ regardless of increases in exercise intensity; subjects' voluntary exhaustion; respiratory exchange ratio higher than 1.10; blood lactate concentration after test higher than $8.0 \mathrm{mmol.}^{-1}$; maximum heart rate predicted by age $(220 \text {-age })^{2}$. $\mathrm{VO}_{2}$ plateau was determined when the difference in oxygen consumption during the last 30 seconds in the last two final stages was $\leq 2.1 \mathrm{ml}^{\mathrm{kg}}{ }^{-1}$. $\mathrm{min}^{-1}$. $\mathrm{WVO}_{2}$ max was established as the maximum power at $\mathrm{VO}_{2}$ max value.

\section{Test with constants loads}

The cycle ergometer, saddle height, pedal pace, warm-up, interruption criterion and $\mathrm{VO}_{2}$ measurement in the exercises with constants loads were the same as in the progressive test until exhaustion. Subjects exercised for ten minutes, or until voluntary exhaustion, in six tests with intensities below the $\mathrm{WVO}_{2}$ max: 40, 50, 60, 70, 80 and $90 \%$ of $\mathrm{WVO}_{2}$ max and one above $\mathrm{WVO}_{2} \max$ $\left(110 \mathrm{WVO}_{2} \max \right)$. The rest interval between tests was approximately ten minutes, or until subjects return to $\mathrm{VO}_{2} \mathrm{LB}$ values. Mean $\mathrm{VO}_{2}$ values during the last minute of the test was used to represent the $\mathrm{VO}_{2}$ in these tests.

\section{Calculations}

The arithmetic mean of $\mathrm{VO}_{2}$ during the last 30 seconds in the sub- $\mathrm{WVO}_{2}$ max exercises was plotted with its respective intensities in order to develop individuals' linear regression equations. The angular coefficients produced by these equations were used to estimate the oxygen demand $\left(\mathrm{VO}_{2} \mathrm{DEM}\right)$ in the supra- $\mathrm{WVO}_{2}$ max exercise (equation described below). The trapezium method was used to calculate $\mathrm{VO}_{2}$ area in respect to the duration time of supra-WVO2max exercise. After that, accumulated $\mathrm{VO}_{2}\left(\mathrm{VO}_{2} \mathrm{ACUM}\right)$, that is, the area under the curve of $\mathrm{VO}_{2}$-time, was determine from the $\mathrm{VO}_{2} \mathrm{LB}^{10}$. The MAOD was established as the $\mathrm{VO}_{2} \mathrm{DEM}$ minus $\mathrm{VO}_{2} \mathrm{ACUM}$.

$$
\mathrm{VO}_{2} \mathrm{DEM}=\left[\left(\mathrm{b}^{*} 110 / 60\right) . \mathrm{t}\right]
$$

Where $\mathrm{VO}_{2} \mathrm{DEM}$ is the estimated $\mathrm{O}_{2}$ demand during supra-WVO $\max$ exercise; 110 is the intensity of the supra- $\mathrm{WVO}_{2}$ max exercise; $b$ is the angular coefficient in $1 . \mathrm{min}^{-1}$ obtained from the linear regression in the $\mathrm{VO}_{2}$-intensities in the sub- $\mathrm{WVO}_{2}$ max tests; $t$ is the total duration time of exercise expressed in seconds.

\section{Statistical analyses}

All analyses were performed with the SPSS software (version 13.0, Chicago, USA). Data normality was verified by Shapiro-Wilk test and all presented normal distribution. Data are reported as means and standard deviation (SD). The correlation coefficient between $\triangle \mathrm{VO}_{2}$ and $\mathrm{MAOD}$ was determined with Pearson linear correlation. $\mathrm{VO}_{2} \max$ and the $90 \% \mathrm{VO}_{2}$ of the $\mathrm{WVO}_{2}$ max values were compared by a paired $\mathrm{T}$ test. The unpaired $\mathrm{T}$ test was used for between-group comparisons (plateau vs. non-plateau) for all the dependent variables $\left(\mathrm{VO}_{2} \mathrm{max}, \mathrm{MAOD}\right.$, peak power, peak heart rate, respiratory exchange ratio $[\mathrm{R}]$, peak blood lactate concentration, ventilatory threshold of $\mathrm{VO}_{2}$, and $\%$ of ventilatory threshold of $\mathrm{VO}_{2}$ related to $\mathrm{VO}_{2}$ peak). The level of significance adopted was 5\% (p<0.05).

\section{Results}

Variables related to the progressive test are presented in TABLE 1. It was not observed significant differences between $\mathrm{VO}_{2} \max$ and $\mathrm{VO}_{2}$ peak obtained at $90 \%$ of $\mathrm{WVO}_{2} \max (\mathrm{p}>0.05)$.

The between-group comparisons revealed no significant differences for the dependent variables: maximum oxygen consumption ( $\left.\mathrm{VO}_{2} \mathrm{max}\right)$, peak power, peak heart rate, respiratory exchange ratio, peak blood lactate concentration, $\mathrm{VO}_{2}$ at the ventilatory threshold and \% of the $\mathrm{VO}_{2}$ of the ventilatory threshold in respect to $\mathrm{VO}_{2} \max$ (TABLE 2). 
TABLE 1 - Variables obtained during the progressive test $(n=9)$.

Values are presented as mean \pm standarddeviation.

$\mathrm{VO}_{2}$ max: maximum oxygen consumption;

[La-]peak: peak blood lactate concentration.

$\mathrm{VO}_{2}$ max: maximum oxygen consumption;

$\mathrm{W}_{\mathrm{vT}}$ : power ventilator threshold;

$\mathrm{VO}_{2} \mathrm{VT}$ : oxygen consumption at ventilatory threshold; VT: ventilatory threshold; $\mathrm{R}$ : respiratory exchange ratio.

The left panel refers to subjects that presented plateau, whereas the right panel represent all subjects (plateau and non-plateau).
$\mathrm{VO}_{2} \max \left(1 . \mathrm{min}^{-1}\right)$

$3.0 \pm 0.5$

$\mathrm{VO}_{2} \max \left(\mathrm{ml} \cdot \mathrm{kg}^{-1} \cdot \mathrm{min}^{-1}\right)$

$41.3 \pm 5.7$

Respiratory Exchange ratio (R)

$1.29 \pm 0.09$

Maximum power (Watts)

Total duration time ( $\mathrm{min}$ )

$247 \pm 39$

$8 \pm 1$

$180 \pm 9$

Maximum heart rate (bpm)

$10.3 \pm 1.4$

TABLE 2 - Between-group comparisons (plateau vs. non-plateau) for the progressive test variables.

\begin{tabular}{lcc}
\hline & Grupo platô & Grupo sem platô \\
\hline $\mathrm{VO}_{2} \max \left(\mathrm{ml} \mathrm{kg}^{-1} \cdot \mathrm{min}^{-1}\right)$ & $41.9(3.9)$ & $40.6(8.7)$ \\
Peak power $(\mathrm{W})$ & $264(39)$ & $225(30)$ \\
$\mathrm{W}_{\mathrm{VT}}$ & $180(36.7)$ & $172.5(28.7)$ \\
$\mathrm{VO}_{2} \mathrm{VT}$ & $31.0(2.1)$ & $34.1(5.5)$ \\
$\mathrm{VT}\left(\% \mathrm{VO}_{2} \max \right)$ & $74.6(8.2)$ & $84.7(5.7)$ \\
$\mathrm{R}$ & $1.28(0.11)$ & $1.32(0.03)$ \\
Peak lactate $\left(\mathrm{mmol.1}{ }^{-1}\right)$ & $10.8(0.9)$ & $10.1(1.8)$ \\
Peak heart rate $(\mathrm{bpm})$ & $180(6)$ & $178(14)$ \\
\hline
\end{tabular}

Five out of nine subjects presented $\mathrm{VO}_{2}$ plateau $(55 \%$ of the subjects). The correlation analysis in these subjects (FIGURE 1, left panel) showed a non-significant inverse correlation between $\triangle \mathrm{VO}_{2}$ and MAOD $(\mathrm{r}=-0.61, \mathrm{p}$ $=0.270)$. Similar non-significant result was observed when pooling data from all subjects $(r=0.28 ; \mathrm{p}=0.464)$.
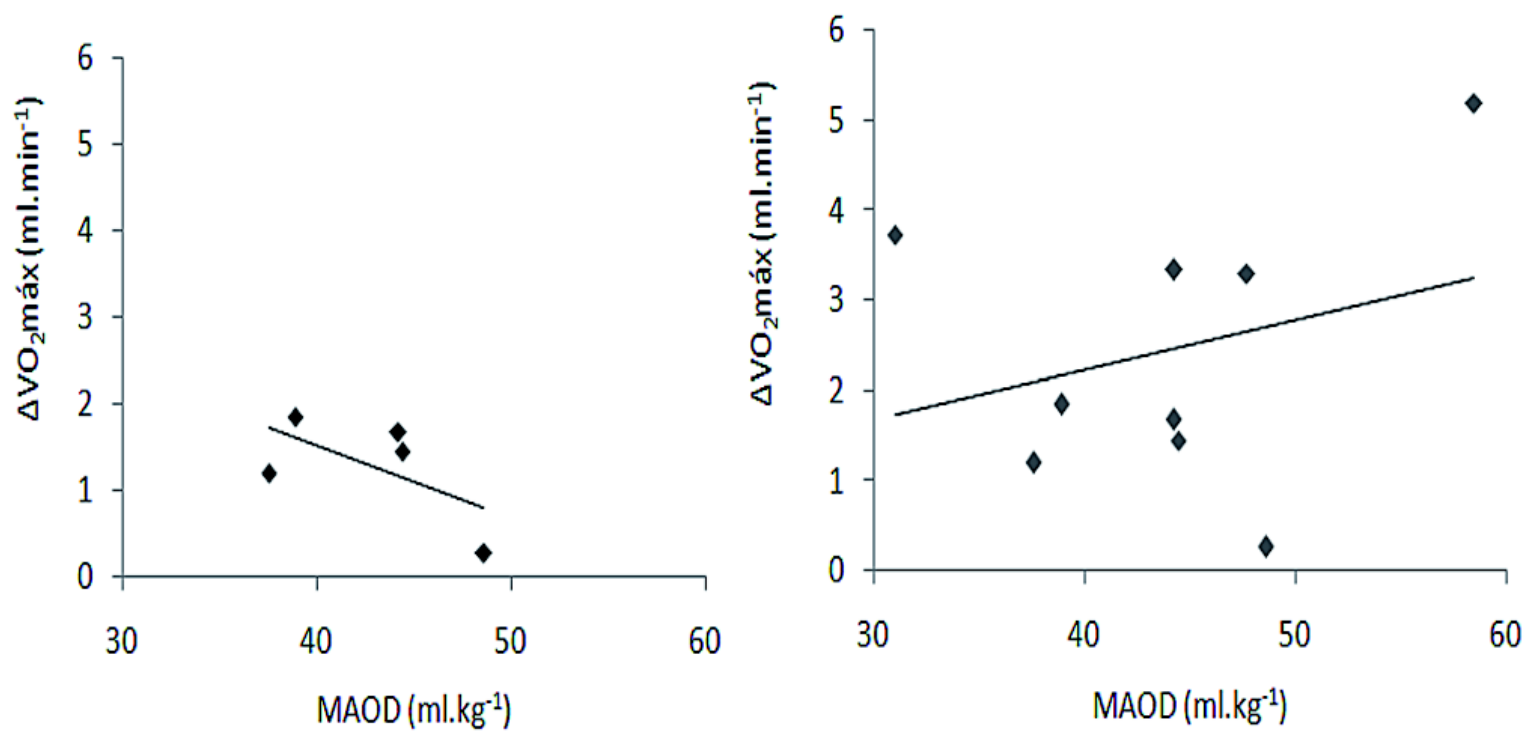

FIGURE 1 - Coefficient correlation between rate of increase in oxygen consumption $\left(\Delta \mathrm{VO}_{2} \max \right)$ and maximum accumulated oxygen deficit (MAOD).

868 • Rev Bras Educ Fís Esporte, (São Paulo) 2016 Out-Dez; 3o(4):865-71 


\section{Discussion}

The aim of the present study was to verify the relationship between anaerobic capacity and $\mathrm{VO}_{2}$ plateau incidence in physically active subjects. Our hypothesis was that MAOD would be positively associated with $\mathrm{VO}_{2}$ plateau. However, the results from the present study showed that $\mathrm{VO}_{2}$ plateau incidence does not seems to be associated with the anaerobic capacity in physically active subjects.

The $\mathrm{VO}_{2}$ max has been utilized to assess the maximum aerobic power ${ }^{1-2}$. The presence of plateau is considered a key criterion to determine if the value obtained during the test can be considered as maximum ${ }^{19}$. However, not all subjects are capable to achieve plateaus state. Previous studies demonstrated a high heterogeneity of plateau incidence between 12 to $59 \%{ }^{1,18,23-26}$. Studies in highly trained athletes showed similar or even lower percentage of plateau incidence as in the present study. Lucia et al. ${ }^{25}$ reported a plateau incidence of $47 \%$ in elite professional cyclists, whereas DOHERTY $^{21}$ showed a plateau incidence of $25 \%$ and $39 \%$ for men and women, respectively in Olympic athletes runners of medium and long distance. In the present study, five out of nine subjects presented plateau. These results are similar to Gordon et al. ${ }^{1}$ that observed plateau presence in four out of nine (44.4\%) highly training cyclists.

In the present study, we observed a non-significant correlation between MAOD and $\triangle \mathrm{VO}_{2}$, which do not corroborate with the above-mentioned study ${ }^{1}$, given that it was observed a significant negative correlation between variables $(\mathrm{r}=-0.77, \mathrm{p}=0.008)$ in highly trained cyclists that presented plateau $\left(\mathrm{VO}_{2} \max =59.3 \pm 4.8 \mathrm{ml} \cdot \mathrm{kg}^{-1} \cdot \mathrm{min}^{-1}\right)$. This result suggest that, in physically active subjects, others variables seems to affect the plateau incidence, in addition to the anaerobic capacity. It has been suggested that the plateau incidence is associated with the individual capacity to support high levels of fatigue and its resistance to pain ${ }^{16}$. However, highly trained athletes, which are familiarized with high levels of effort and pain sensation during training session and/or competitions, did not show higher incidence of plateau ${ }^{21,25}$, strengthening the idea of other intervening variables. Ретот et al. ${ }^{17}$ have suggested that the incapacity to reach plateau in incremental test is due to the incapacity to support the high power levels demanded during the test final stages. In their study, an incremental test was performed to verify the $\mathrm{VO}_{2} \max$. For the subjects that presented plateau or for those that the secondary criterion was achieved, even in the absence of plateau, a new test was performed. Test started similarly to the incremental test, with increases in load in a time function. When subjects achieved its $\mathrm{VO}_{2} \max$, determined in the first test, the power was reduced until the subject was able to maintain the $\mathrm{VO}_{2}$ values previously determined. Using this protocol, $100 \%$ of subjects were able to reach plateau. Another study that corroborate with the present results is the RrverABrown et al. ${ }^{23}$ where the incidence of plateau in prepubertal boys was 33\% and, it was not observed any relationship between anaerobic power and plateau incidence. This results seems reinforce that other variables may be relevant to plateau incidence, as children's shown lower anaerobic capacity levels, thus, it would be expected a reduced incidence of plateau.

Additionally, results from the present study demonstrated that $\mathrm{VO}_{2}$ peak at $90 \%$ of $\mathrm{WVO}_{2}$ max was not significant different from $\mathrm{VO}_{2}$ max. That is, the $\mathrm{VO}_{2}$ values obtained during the final TI can be considered as maximum, even for those subjects that did not reach plateau. Indeed, exercise performed within this level of effort $\left(-90 \%\right.$ of $\left.\mathrm{WVO}_{2} \max \right)$ usually achieve the $\mathrm{VO}_{2}$ max values ${ }^{27}$. Furthermore, peak heart rate, $\mathrm{R}$ and blood lactate concentrations reached elevated values, confirming that the values observed can be considered as maximum for all subjects ${ }^{2}$. It was also demonstrated that individuals with higher levels of maximum aerobic power did not present a higher incidence of plateau. Altogether, these results suggests that when physically active subjects reach the first load correspondent to $\mathrm{VO}_{2}$ max they interrupt the exercise.

Importantly, the present study has some limitations. First, only nine subjects were evaluated, which could have been insufficient to observe significant correlations between variables. Especially in the subanalysis, in which it was considered only the subjects that presented plateau $(n=5)$. In this analysis we observed a negative correlation, however, it was not statistical significant. In order to observe significant correlations with small sample sizes it is necessary values nears of one $(+1$ or -1$)$, which increase the chance for type II error (observe non-significant correlations between variables, when in fact there is significant correlations $)^{28}$. Limitations related to the use of MAOD to determine the anaerobic capacity should be highlighted, an impossibility to directly measure the variable, due to a lack of gold-standard method to determine the anaerobic 
capacity; the use of $\mathrm{VO}_{2}$ to estimate the energetic metabolism that is measured as the whole-body, not being possible to account for the demand imposed by the musculoskeletal system during the exercise task; the contribution of the anaerobic lactic system on intensities above the anaerobic threshold are not excluded of the calculations and the slow component of $\mathrm{VO}_{2}$ during the higher intensities may overestimate the $\mathrm{O}_{2}$ demand. Despite these limitations, the
MAOD has been considered as a decent method to estimate the anaerobic capacity ${ }^{6,29-30}$.

In short, it was observed non-significant correlations between plateau and anaerobic capacity, suggesting that the plateau incidence it is not related only with the anaerobic capacity in physically active subjects. Altogether, these results indicate that for subjects with this level of training, the anaerobic capacity it is not the main predominant factor to plateau incidence.

\section{Resumo}

0 platô do $\mathrm{VO}_{2}$ max está associado à capacidade anaeróbia em indivíduos fisicamente ativos

0 presente estudo teve como objetivo verificar se a incidência do platô está relacionada com a capacidade anaeróbia. Para tanto, nove individuos fisicamente ativos (idade: $23 \pm 4$ anos; massa corporal: $72,4 \pm$ $8,2 \mathrm{~kg}$; estatura: $\left.176,4 \pm 6,8 \mathrm{~cm} ; \mathrm{VO}_{2} \max : 41,3 \pm 5,7 \mathrm{ml}^{\mathrm{kg}}{ }^{-1} \cdot \mathrm{min}^{-1}\right)$ participaram do presente estudo. Eles foram submetidos aos seguintes testes, realizados em cicloergômetro: a) um teste incremental máximo para a determinação do $\mathrm{VO}_{2} \mathrm{max}_{\text {; }}$ ) seis testes submáximos para determinar a demanda supramáxima de $\mathrm{O}_{2}$; c) um teste supramáximo para a determinação do déficit máximo acumulado de oxigênio (MAOD). 0 platô foi caracterizado quando a diferença do $\mathrm{VO}_{2}$ entre os dois últimos estágios do teste incremental foi $\leq 2,1 \mathrm{ml} \cdot \mathrm{kg}^{-1} \cdot \mathrm{min}^{-1}$. Foi observada uma correlação inversa, porém não significante, entre e o MAOD e 0 platô do $\mathrm{VO}_{2}(r=-0,61 ; p>0,05)$. Dessa forma, parece que a capacidade anaeróbia não é fator decisivo para determinar a incidência de platô no $\mathrm{VO}_{2}$ em indivíduos fisicamente ativos.

PalavRAS-Chave: MAOD; Estabilização do consumo de oxigênio; Déficit de oxigênio; Teste incremental; Teste supramáximo.

\section{References}

1. Gordon D, Hopkins S, King C, Keiller D, Barnes RJ. Incidence of plateau at $\mathrm{VO}_{2}$ max is dependent on the anaerobic capacity. Int J Sports Med. 2011;32:1-6.

2. Howley ET, Basset DT, Welch HG. Criteria for maximal oxygen uptake: review and commentary. Med Sci Sports Exerc. 1995;27:1292-301.

3. Shephard RJ, Allenm C, Benade AJ, et al. The maximum oxygen intake: an international reference standard of cardio-respiratory fitness. Bull World Health Organ. 1968;38:757-64.

4. Basset DR, Howley ET. Limiting factors for maximum oxygen uptake and determinants of endurance performance. Med Sci Sports Exerc. 2000;32:70-84.

5. Howley TH, Basset DR. Criteria for maximal oxygen uptake: review and commentary. Med Sci Sports Exerc. 1995; 27:1292-301.

6. Bertuzzi R, Bueno S, Pasqua LA, et al. Bioenergetics and neuromuscular determinants of the time to exhaustion at velocity corresponding to $\mathrm{VO}_{2} \max$ in recreational long-distance runners. J Strength Cond Res. 2012; 26:2096-102.

7. Nummela TA, Paavolainen LM, Sharwood KA, Lambert MI, Noakes TD, Rusko HK. Neuromuscular factors determining $5 \mathrm{~km}$ running performance and running economy in well-trained athletes. Eur J Appl Physiol. 2006;97:1-8.

8. Brandon LJ. Physiological factors associated with middle distance running performance. Sports Med. 1995;19:268-77.

9. Hickson RC, Bomze HA, Holloszy JO. Linear increase in aerobic power induced by a strenuous program of endurance exercise. J Appl Physiol Respir Environ Exerc Physiol. 1977;42:372-6. 
10. Warburton DE, McKenzi DC, Haykowsky MJ, et al. Effectiveness of high-intensity interval training for the rehabilitation of patients with coronary artery disease. Am J Cardiol. 2005;95:1080-4.

11. Melchiorri G, Ronconi M, Triossi T, et al. Detraining in young soccer players. J Sports Med Phys Fitness. 2014;54:27-33.

12. Neufer PD. The effect of detraining and reduced training on the physiological adaptations to aerobic exercise training. Sports Med. 1989;8:302-20.

13. Keteyian SJ, Brawner CA, Savage PD, et al. Peak aerobic capacity predicts prognosis in patients with coronary heart disease. Am Heart J. 2008;156:292-300.

14. Beitler JR, Awad KM, Bakker JP, et al. Obstructive sleep apnea is associated with impaired exercise capacity: a cross-sectional study. J Clin Sleep Med. 2014;10:1199-204.

15. Day JR, Rossiter HB, Coats EM, Skasick A, Whipp BJ. The maximally attainable $\mathrm{VO}_{2}$ during exercise in humans: the peak vs. maximum issue. J Appl Physiol. 2003;95:1901-7.

16. Wagner PD. New ideas on limitations to $\mathrm{VO}_{2}$ max. Exerc Sport Sci Rev. 2000;28:10-4.

17. Petot H, Meilland R, Moyec LL, Mille-Hamard L, Billat VL. A new incremental test for $\mathrm{VO}_{2}$ max accurate measurement by increasing $\mathrm{VO}_{2}$ max plateau duration allowing the investigation of its limiting factors. Eur J Appl Physiol. 2012;112:2267-76.

18. Rossiter HB, Kowalchuck JM, Whipp BJ. A test to establish maximum $\mathrm{O}_{2}$ uptake despite no plateau in the $\mathrm{O}_{2}$ uptake response to ramp incremental exercise. J Appl Physiol. 2006;100:764-70.

19. Snell PG, Stray-Gundersen J, Levine BD, Hawkins MN, Raven PB. Maximal oxygen uptake as a parametric measure of cardiorespiratory capacity. Med Sci Sports Exerc. 2007;39:103-7.

20. Gastin PB, Costill DL, Lawson DL, Krzeminski, K, McConell G. Accumulated oxygen deficit during supramaximal all-out and constant intensity exercise. Med Sci Sports Exerc. 1995;27:255-63.

21. Doherty M. The effects of caffeine on the maximal accumulated oxygen deficit and short-term running performance. Int J Sport Nutr. 1998;8:95-104.

22. Marth PD, Woods RR, Hill DW. Influence on time of day on anaerobic capacity. Percept Mot Skills. 1998;86:592-4.

23. Rivera-Brown AM, Alvarez M, Rodríguez-Santana JR, Benetti PJ. Anaerobic power and achievement of VO2 plateau in pre-pubertal boys. Int J Sports Med. 2011;22:111-5.

24. Doherty M, Nobbs L, Noakes TD. Low frequency of the "plateau phenomenon" during maximal exercise in elite British athletes. Eur J Appl Physiol. 2003;89:619-23.

25. Lucía A, Rabacán M, Hoyos J, et al. Frequency of the $\mathrm{VO}_{2}$ max plateau phenomenon in world-class cyclists. Int J Sports Med. 2006;27:984-92.

26. Astorino TA. Alterations in $\mathrm{VO}_{2}$ max and $\mathrm{VO}_{2}$ plateau with manipulation of sampling interval. Clin Physiol Funct Imaging. 2009;29:60-7.

27. Bertuzzi RCM, Rumenig-Souza E. Resposta cinética do consumo de oxigênio: relação entre metabolismo aeróbio e atp-cp. Arq Mov. 2009;5:99-118.

28. Thomas JR, Nelson JK. Métodos de pesquisa em atividade física. Porto Alegre: Artmed; 2002.

29. Scott CB, Roby FB, Lohman TG, Bunt JC. The maximally accumulated oxygen deficit as an indicator of anaerobic capacity. Med Sci Sports Exerc. 1991;23:618-24.

30. Gastin PB. Quantification of anaerobic capacity. Scand J Med Sci Sports. 1994;4:91-112.

\begin{tabular}{r|l} 
ENDEREÇo & \\
Renata Gonçalves Silva & \\
Escola de Educação Física e Esporte - USP & Submitted: 06/10/2014 \\
Av. Prof. Mello de Moraes, 65 & 1a. Review: 03/18/2015 \\
05508-030 - São Paulo - SP - BRASIL & 2a. Review: 08/04/2015 \\
e-mail: resilva@usp.br & Accepted: 09/29/2015 \\
&
\end{tabular}

